\title{
“BRAIN DRAIN, BRAIN GAIN... BRAIN SUSTAIN?" Challenges in building portuguese human research capacity
}

\author{
Sandra Hasanefendic \\ Instituto Universitário de Lisboa (ISCTE-IUL), Lisbon, Portugal \\ Vrije Universiteit Amsterdam, The Netherlands \\ Center for Innovation, Technology and Policy Research, IN+, Instituto Superior Técnico, Lisbon, \\ Portugal
}

\begin{abstract}
This paper presents a systematic but essentially descriptive account of the policy measure of stimulating human research capacity development under the policy program "Commitment to Science" in Portugal in the period 2006-2009. It explores the conditions that contributed to the development of the policy program and the measure to contract 1000 doctorates to Portuguese public and private research and development $(R \& D)$ units, and addresses the outcomes of the program within the overall science and technology policy development in Portugal. The results underline the importance of strategic policy planning and stable funding allocation for the success of policy initiatives. Further, the results indicate that the policy initiative was successful inasmuch as the Portuguese scientific community significantly increased, and also internationalised; however subsequent economic and political austerity hampered the absorption of young researchers into the public and private systems. The previous situation has been reversed since 2011 with a significant and perceivable decline in public investment in research, a decline of budgetary allocations to universities, and the migration of young researchers abroad. The analysis urges the revision of science and technology policy in Portugal and funding mechanisms available to R\&D in consideration of the country's socioeconomic situation, and with respect to other segments of the economic ecosystem.
\end{abstract}

Keywords: human resources, policy program, science and technology.

Resumo Este artigo apresenta uma análise sistemática mas essencialmente descritiva da iniciativa política de estimular o desenvolvimento de recursos humanos em ciência e tecnologia, no âmbito do programa de política “Compromisso com a Ciência”, em Portugal, no período de 2006-2009. O artigo explora as condições que contribuíram para o desenvolvimento do programa de políticas, as medidas para contratar 1000 doutorados para o setor de investigação público e privado português, abordando também os resultados do programa no âmbito de desenvolvimento de políticas de ciência e tecnologia em Portugal. Os resultados sublinham a importância do planeamento estratégico e da alocação de financiamento estável para o sucesso das iniciativas políticas. Além disso, os resultados indicam que a iniciativa foi bem-sucedida, dado o aumento significativo na comunidade científica portuguesa, e também a sua internacionalização; no entanto, a subsequente austeridade económica e política dificultou a absorção de jovens investigadores nos setores público e privado. A anterior situação foi revertida desde 2011, com um declínio significativo e percetível do investimento público em investigação, um declínio de dotações orçamentais às universidades e a emigração de jovens investigadores para o estrangeiro. A análise insta a revisão das políticas de ciência e tecnologia em Portugal e mecanismos de financiamento disponíveis para investigação, tendo em consideração a situação socioeconómica do país, e em relação a outros segmentos do ecossistema económico.

Palavras-chave: recursos humanos, programa de política, ciência e tecnologia.

Résumé Cet article présente une étude systématique et essentiellement descriptive de l'initiative politique de stimuler le développement des capacités de recherche humaine, réalisée au Portugal pendant la période 2006-2009, suivant la politique du programme "L'Engagement pour la Science". Ce travail explore les conditions qui ont contribué au développement de ce programme, aux 1000 doctorants engagés dans les unités de recherche et développement des centres portugais, publiques et privés, et l'impact des résultats du programme dans le développement des politiques globales de science et technologie au Portugal. Les résultats soulignent l'importance de la planification stratégique des politiques et du financement stable pour garantir le succès de ces initiatives. De plus, les résultats indiquent que l'initiative a réussi, étant donnée l'augmentation et l'internationalisation significative de la communauté scientifique portugaise. Cependant, l'austérité politique et économique postérieure du pays a difficulté l'absorption de jeunes chercheurs dans les systèmes publiques et privés. Depuis 2011, la situation s'est retournée et il est possible d'observer une baisse significative et perceptible 
dans l'investissement public en recherche, une baisse dans les budgets cédés aux universités, ainsi que la migration des jeunes chercheurs à l'étranger. Cette analyse signale l'importance d'une révision des politiques de science et technologie au Portugal et de ses mécanismes de financement pour la recherche et le développement, tout en considérant la situation socioéconomique du pays et le respect envers d'autres segments de l'écosystème économique.

Mots-clés: ressources humaines, programme politique, science et technologie.

Resumen Este artículo presenta un estudio sistemático y al mismo tiempo descriptivo de la iniciativa política que se llevó a cabo en Portugal durante el periodo 2006-2009, bajo el programa político "Compromiso con la Ciencia", sobre cómo estimular el desarrollo de la capacidad humana de investigación. Este trabajo explora: las condiciones que contribuyeron al desarrollo de dicho programa, la medida de contratar a 1000 dotores en las unidades de investigación y desarrollo de centros públicos y privados portugueses y el impacto de los resultados del programa en el desarrollo de las políticas de ciencia y tecnología en Portugal. Los resultados subrayan la importancia de la planificación estratégica de las políticas y la asignación estable de financiación, para el éxito de tales iniciativas. Aún más, los resultados indican que la iniciativa fue un éxito, ya que la comunidad científica portuguesa aumentó significativamente en número y en grado de internacionalización. Sin embargo, la posterior austeridad política y económica, obstaculizó la absorción de estos jóvenes investigadores por los sistemas públicos y privados. Desde 2011 la situación se ha invertido, se observa una disminución significativa y perceptible de la inversión pública en investigación, una disminución de las asignaciones presupuestarias a las universidades, así como la migración de los jóvenes investigadores hacia el extranjero. Este análisis insta a la revisión de las políticas de ciencia y tecnología en Portugal y de sus mecanismos de financiación para la investigación y el desarrollo, considerando la situación socioeconómica del país, y con respecto a otros segmentos del ecosistema económico.

Palabras-clave: recursos humanos, programas políticos, ciencia y tecnología.

\section{Introduction}

Over the past three decades, the Portuguese science and technology (S\&T) system has been growing with intense and large-scale changes in science and technology policies targeting the improvement of scientific infrastructure: assessment, evaluation and investments in $R \& D$, and training of human resources in S\&T. The underdeveloped tertiary education system, with its limited knowledge base, research capacity and access was recognized as a problem impeding economic and social growth of Portugal in the late 1960s (Gonçalves and Caraça, 1987; Heitor and Horta, 2012; Heitor, Horta and Mendonça, 2014). Government at the time kept itself at a distance from science and scientific culture (Gago, 1990), creating short-term polices and investing in science and technology at negligible rates. Research was underdeveloped and undertaken in isolation by selected state laboratories (see Heitor, Horta and Mendonça, 2014). There were no incentives to higher education qualification and during this period many Portuguese scientists and scholars left the country in pursuit of education and specialization (Heitor and Horta, 2012), which left higher education institutions without adequately qualified teaching and research staff.

Significant and stable increases in support for developing the S\&T system in Portugal prevailed from the late 1960s. For example, the establishment of the 
National Committee of Scientific and Technological Research (Junta Nacional de Investigação Científica e Tecnológica, JNICT) in 1967 "marked the beginning of science planning" (Heitor, Horta and Mendonça, 2014: 12; Rollo, Ribeiro and Meireles, 2013). The consolidation of the program "Ciência - Criação de Infraestruturas Nacionais de Ciência, Investigação e Desenvolvimento" in 1993 stimulated the growth in doctoral qualifications in the country with more than 3000 fellowships granted (Heitor, Horta and Mendonça, 2014), and the creation of the Ministry for Science and Technology in 1995 introduced many changes in the S\&T infrastructure. The Ministry undertook the reform of assessment and evaluation of research and restructured JNICT into three different institutions in 1997: Portuguese Foundation for Science and Technology (Fundação para Ciência e a Tecnologia, FCT), which is responsible for the evaluation and financing of research in Portugal, Institute for International Science and Technology Cooperation (Instituto para a Cooperação Científica e Tecnológica Internacional, ICCTI), which is responsible for international cooperation in science and technology, and Observatory of Science and Technology (Observatório da Ciência e Tecnologia, OCT) ${ }^{1}$ which studies the national scientific and technological capacity. The Ministry also fostered the promotion of scientific culture through programs such as "Ciência Viva" and "Associated Laboratories". ${ }^{2}$ By 2000, Portugal had established favourable conditions for the development of S\&T and consolidated R\&D infrastructure, which enabled the reinforcement of policies to foster further knowledge creation and growth.

In 2006, the Portuguese Government launched the "Commitment to Science" ("Compromisso com a Ciência") policy program. It was the most comprehensive policy program so far and aimed to stimulate scientific development and enlarge research capacity within the Portuguese economy via targeted policy measures (Horta and Hasanefendic, 2015), given that the number of researchers per thousand active population was still one of the lowest in the EU in $2003-3.7$, representing $62 \%$ of the EU average (see Pordata, 2012). Within the three years of its full implementation and sustained investment, the "Commitment to Science" program reversed the trend of poor scientific and research capacity in Portugal. The program stimulated an expansion of the scientific community with the number of doctoral students growing to 1,569 in 2009 and the number of researchers in $R \& D$ in higher education increasing from 10,956 in 2005 to 28,830 in 2010 (GPEARI/MEC, 2011a; 2011b; OECD, 2011). It also contributed to the internationalization of public R\&D units in Portugal and mobility of Portuguese scientists (see Fontes, 2007) and incentivized private investment in R\&D in Portugal. For

1 Now called "Observatory for Science, Technology and Qualifications "(see http://www.dgeec.mec.pt/np4/119/).

2 "Ciência Viva" is the National Agency for Scientific and Technological Culture, which aims for greater appreciation of science in Portuguese society, through initiatives to promote experimental science teaching in schools, national science communication campaigns and a national network of Ciência Viva centers, which are interactive museums of science and technology. Associated Laboratories were created in 1997 and are organized around thematic areas and may provide assistance to the Government when designing public policies. They usually involve several research units from multiple Portuguese universities or research institutes. 
example, business spending on $R \& D$, out of total share of gross expenditure in R\&D, increased about 30\% in the period between 2005 and 2009 (MCTES, 2010). By 2009 Portugal had advanced to a GERD/GDP ratio of $1.66 \%$, with the private sector becoming the most important R\&D performer, boasting a $47.0 \%$ BERD/GERD share in 2009. However, after 2010 the economic and financial crisis largely affected this growing trend. Austerity measures stemming from the agreement entered into with the so-called "troika" (International Monetary Fund, European Central Bank and European Commission) had negative consequences on the development of science and technology in Portugal in general, and the continuation of the program and the policy initiative to stimulate further development of research capacity in particular. There has been a significant and perceptible decline in public investment in research since 2011, a decline in budgetary allocations to universities and an increase in migration of young researchers abroad, signalling a new era of brain drain (Horta and Hasanefendic, 2015).

This research analysis addresses the achievements of the "Commitment to Science" policy program and its goals of contracting 1000 doctorates to R\&D units in Portugal against the backdrop of its formative challenges and explores its outcomes within the overall framework for the development of science and technology policy in Portugal. The following section briefly explains the methodological choice of the paper following the stages in the policy process to depict the way in which the policy program and policy measures were formulated at the Governmental level, the mechanisms by which they were implemented and the outcomes that suggest whether they were a success or a failure. The discussion section reflects on the major achievements of the program and the policy measure in stimulating the development of human research capacity in Portugal. In particular, it draws on statistical data to show the positive effect related to the advanced qualification of human resources at public and private $R \& D$ units. In the conclusion, the outcomes of the policy program are reflected upon critically and challenged against the assumptions that recent Governmental efforts have not addressed science and technology policy at the highest political level.

\section{Policy analysis as a methodological choice}

The paper uses policy cycle analysis (Fischer and Miller, 2006) as an analytical framework to systematically describe the policy initiative of developing human research capacity in S\&T within the context of the policy program "Commitment to Science" and the measure to hire 1000 doctorates to Portuguese R\&D units. The policy cycle analysis is used to highlight the preconditions to the policy, the central factors influencing its development and diverse outcomes (Jann and Wegrich, 2006). Despite its shortcomings and limitations, the policy cycle approach is useful to evaluate policy implementation in a heuristic manner and can shed light on the complexity behind the policymaking process (Mayntz, 1983). Drawing on these principles, the paper explores the policy context to describe the genesis of the policy program and to evaluate the development of a targeted 
policy measure that involved contracting 1000 doctorates for private and public R\&D units in Portugal.

Policy cycle analysis informs logical sequences of recurring events (Bridgman and Davis, 2003), and although there are some variations in stages of the policy cycle (Howlett and Ramesh, 2003), the following are common in the analysis: background to the policy and agenda setting (defining problems and raising issues); policy formulation (suggesting solutions to raised issues as authoritative decisions); policy implementation (defining the way in which the policy is enforced and under what conditions the policy is administered); policy evaluation (relying on statistical data to assess the impact of a given policy that is implemented). The rationale for observing each stage separately comes from the understanding that each stage contains different activities that contribute to the outcome. Existing documental data, Governmental reports and literature that discussed the program or the policy initiative were used for the analysis, along with descriptive statistics to define stages of the policy cycle.

\section{Background to the "Commitment to Science" policy program}

In 2005, the Portuguese Socialist Party (PS) won the absolute majority in the general elections and occupied 120 of 230 seats in Parliament. The newly formed Government placed educational reforms at the top of their agenda and gave high priority to the development of science and technology. In the area of higher education, the Go-

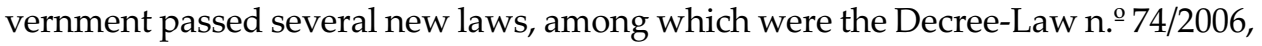
introducing Bologna, a new framework for higher education institutions (RJIES) Law n. 62/2007 of September 10; and a new legal framework for the evaluation of higher education (RJAES) - Law n. ${ }^{-38 / 2007}$ of August 16. Other legal reforms concerned the establishment of the accreditation and evaluation agency (Decree-Law n.. 82/2007 of November 5), regulations for the recognition of foreign academic degrees (Decree-Law n. ${ }^{\circ}$ 341/2007 of October 12) and course change, transfer or re-entry into higher education (Ministerial Order n. ${ }^{\circ}$ 401/2007 of April 5). The new Government also pursued further S\&T development in the country by launching the "Technological Plan" in May 2006 along with "Commitment to Science," the comprehensive policy program aimed at boosting research capacity in S\&T in Portugal, which were strongly underpinned by the 2007 budget (see File, 2008).

\section{Agenda setting for "Commitment to Science"}

\section{European incentives}

In 2003, the European Commissioner for Research, Philipe Busquin created a High Level Group to perform an in-depth study of the condition of human resources in S\&T in Europe. Busquin commented that: 
... excellency in scientific and technological development is a prerogative for the development of Europe. In order for Europe to become the most dynamic knowledge based community in the world and urge the investment in research in Europe thus consolidating the objectives of the Lisbon and Barcelona Treaty, the European Union must find a solution for the scarcity of scientists and researchers in Europe... Enhancing training possibilities and creating opportunities for a research career is fundamental to reach this goal. The recommendations of the High Level Group provide with concrete suggestions on how to overcome this challenge [European Commission Report by the High Level Group on Increasing Human Resources for Science and Technology in Europe, Luxembourg, Office for Official Publications of the European Communities, 2004].

The chairman of the Group was a Portuguese scholar and former Minister for Science and Technology, José Mariano Gago, who consulted 300 institutions, companies, universities, scientific communities, international laboratories and organisations, as well as the Governments of most of the European countries and came up with comprehensive report on the status of human resources within the context of the European S\&T, ${ }^{3}$ which he presented to the High Level Group in July 2004 (FCT, 2009). The report was a consistent and systematic study of recommendations and proposals aiming at raising the qualifications of human resources in science and technology, and thus reaching the Lisbon Strategy targets for European Development. This report was a starting point for drafting the policy program "Commitment to Science," which was to be implemented in Portugal in subsequent years.

The High Level Group reported that the private sector is the greatest employer of scientific staff around Europe, and that the European Governments have not been investing in human resource qualification in the public sector, which has resulted in a lack of human resources in science and technology in this sector with stable employment and concrete career objectives (FCT, 2009). In order to reach the objectives of the Lisbon and the Barcelona Treaty of 3\% of GDP for S\&T, Europe had to reach target of 8 full-time researchers per 1000 active working population.

It is in this European context that the Portuguese Government sought to rapidly develop its research capacity and qualify human resources in S\&T, along with creating more stable national economic conditions and a certain level of maturity of the S\&T system.

\section{Portuguese Government incentives}

The Portuguese Government also felt pressure to improve research capacity and reach Lisbon Targets in terms of human resources in S\&T. The newly formed Ministry for Science, Technology and Higher Education sought to develop a program to stimulate the development of Portuguese research capacity, battle the insufficiency of human resources in S\&T in Portugal and promote the development 
of R\&D units (FCT, 2009). The Ministry of Science, Technology and Higher Education acted as a powerful stakeholder in designing and implementing the "Commitment to Science" policy program as a priority within the framework of immediate political action (see more on powerful stakeholders in Mitchell, Agle and Wood, 1997). On March 29, 2006 the Portuguese Government launched the "Commitment to Science" policy program through a speech to the Portuguese Parliament by Prime Minister José Socrates. The intentions the Prime Minister expressed in this speech were aligned with the "Technological Plan" (see Laranja, 2012), which provided the main background for his Parliamentary address. One important segment of the speech was its concrete stress on the importance of commitments to increase doctoral education, to promote the employment of highly skilled people at R\&D units, thus improving their quality and fostering internationalisation, and to commit public policy to leveraging R\&D investments. ${ }^{4}$

The level of maturity of the S\&T system also played a role in implementing the policy program. The scientific base in Portugal already showed signs of maturity in the system, the result of a set of S\&T policies and programs developed in the early 1990s such as "Ciência" program which promoted advanced training and the "construction of physical infrastructure" among others (Heitor, Horta and Mendonça, 2014: 13). These programs fostered the increase of doctorates and enabled the creation of the much-needed critical mass in science and technology in Portugal. The specific strategy of attracting researchers to public and private R\&D institutions in Portugal was a next step sought through the program.

\section{Policy formulation: "Commitment to Science" and the policy measure "Contractual arrangements for 1000 doctorates"}

The policy program "Commitment to Science," which came to life in April 2006, consisted of seven policy measures to strengthen science policy in Portugal, based on premise that the upgrading of the country's scientific potential is essential for economic growth and social development (FCT, 2009; Heitor and Horta, 2012). In the period, Portugal was far from reaching the necessary targets of the Lisbon Strategy due to scarcity of highly qualified staff in science and technology (3.7 per thousand of active population in 2005; OECD average was around 7 in 2005 - see Pordata, 2012), a low number of doctoral graduates (see GPEARI/MCTES, 2011a; $2011 \mathrm{~b}$ ) and a low percentage of the population with higher education degrees (for 25-64 year-olds only 15\%; OECD average is $31 \%$ in 2012 - see OECD, 2012a).

The policy program identified priorities in terms of: improving scientific and technical competencies, increasing the number of highly qualified human resources (doctoral and postdoctoral researchers), developing R\&D units and organising them in collaborative networks, boosting internationalisation and using

4 The information about the speech and official launch of the Program were found at the website Jornal de Notícias - see: http://www.jn.pt/paginainicial/interior.aspx?content_id=543438 
international activities as evaluation criteria and research commercialisation. Specific policy measures for the development of human research capacity were as follows (to be reached by 2010):

- $\quad$ to reach 5.5 researchers for 1000 of active population (in 2003 there were 3.5 );

- pass from 1000 to 1500 new PhDs per year;

- adapt and consolidate immigration legislation and supporting mechanisms to enable highly qualified human resources from other countries to develop their work in Portugal and make it easier for their families to join; ${ }^{5}$

- increase $\mathrm{PhD}$ scholarships by $60 \%$ via open competition;

- open competition for contractual arrangements with researchers, with the purpose of hiring at least 1000 national and international doctorates of exceptional merit to work at Portuguese higher education institutions and R\&D units.

Contractual arrangements for 1000 doctorates: overview of the policy measure

Contractual arrangements were a policy measure within the framework of the "Commitment to Science" policy program and targeted scientific employment at R\&D units in Portugal. This policy measure consisted of offering five-year research positions to Portuguese and international scientists, which was seen as a way to bring researchers from across all disciplines, from all over the world to Portugal and help intensify the S\&T knowledge base of Portugal. The measure was launched initially in 2007 and 2008 under "Ciência 2007" and "Ciência 2008" programs and aimed to provide support for hiring individuals with doctoral degrees, under the individual employment contract provisions at a variety of Portuguese research units.

FCT was responsible for the implementation of contractual arrangements as it handled the process of candidate selection, the documentation and advertisement of calls, the preparation of rules and guidelines of the competition and funding allocation. Most importantly, it was responsible for the evaluation process of institutions that were participating in the program (FCT, 2009). These were higher education institutions, state laboratories, associate laboratories and other private R\&D institutions and companies, which were duly evaluated for their research and development activities. As these institutions were to host the selected scientists, the evaluation of their scientific production and capacity was considered crucial in the process. Independent international panels evaluated the institutions based on the following criteria (FCT, 2009):

5 Portugal implemented a simplified visa process for highly qualified incoming researchers, who were able to get residency based on their research work in Portugal if in possession of a valid working contract with one of the recognised research units in Portugal - see http://www.fct.pt/documentos/Info_estrangeiros_alt_qualif_EN.pdf 
- proven scientific capacity and scientific production, especially in the past three years;

- a well-developed scientific work plan to embed the contracted researchers and to clarify the influence they would have on the development of the participating institution.

Within the evaluation process, the institutions specified the reception conditions, development activities, and relevant co-financing, as well as the contribution they expected from the candidate in terms of scientific advantages. Positively evaluated research institutions were given a permission to offer contractual arrangements to scientific researchers.

\section{The process of candidate selection}

The competition for research positions at selected institutions commenced in 2007 and was organized by each individual research institution, with assistance from FCT. The applications were received from April 24 to August 30, 2007. The following conditions for application were stipulated (FCT, 2009; 2012):

- The researcher had to hold a doctorate and have at least three years of proven post-doctoral scientific excellence and scientific production. In exceptional cases, the researchers could be considered for evaluation if they had fewer than three years of research experience in a post-doctoral position.

- The competition was open to all nationalities.

- The opening of the competition was announced on the European portal "www.eracareers.pt" along with all other scholarship or research opportunities in Portugal. The vacancy was thus advertised internationally.

- The jury or the committee responsible for assessing the applications was composed of reputable scientists from selected fields, either from Portuguese or foreign internationally recognized institutions. The composition of the committee, as well as their respective CVs, were published on the FCT portal website.

- Appeals were made through FCT, which also handled the writing of reports on the process evaluation as well as the results of the process itself.

In 2008, the second phase of the policy measure of contractual arrangements commenced under the "Ciência 2008" program. Since the host institutions were already evaluated in the previous year, there was no need for another additional assessment of the institutions and the process was much simpler. The calls for pre-selection of the research employment were announced on the European portal "www.eracareers.pt" for the period of three months from mid-June to September 2008 . 


\section{Policy implementation: “Contractual arrangements for 1000 doctorates"}

In 2007, 70 contractual arrangements with institutions were signed and via these FCT approved 600 research positions for the selected institutions. In 2008, there were 3517 applications to 755 calls and 77 institutions submitted concrete proposals to host 708 researchers, which represented approximately $76 \%$ of all the positions offered by institutions. ${ }^{6}$

FCT reported that $62.99 \%$ of all the research positions were situated at R\&D units, $27.4 \%$ at associated laboratories, $8.62 \%$ at state laboratories and $1 \%$ in other entities (2009). By 2009, 264 research units in Portugal hired around 1200 new doctoral researchers, of whom $41 \%$ were foreigners, $56 \%$ men and $44 \%$ women, $43 \%$ in the natural and exact sciences and $24 \%$ in engineering and technology) (MCTES, 2011). The majority of foreign researchers came from EU countries, which showed that Portugal had the potential to attract top researchers to its R\&D units and foster their further specialisation, development and improvement (Horta and Hasanefendic, 2015). According to Heitor, Horta and Mendonça (2014) the number of foreign academics in the Portuguese tertiary education system totalled 1400 in 2009, an increase of $26 \%$ since 2001. Additionally, the number of foreign researchers almost doubled, from nearly 1900 in 2005 (6\% of the total number of researchers) to about 3800 in 2008 (7\% of the total) (FCT, 2014). Such a diverse and heterogeneous $S \& T$ base in terms of nationalities contributed to the process of internationalisation of the Portuguese R\&D institutions as well as accelerated levels of mobility among the Portuguese faculty (Fontes, 2007; FCT, 2009; Araújo, 2009).

\section{Policy evaluation: “Contractual arrangements for 1000 doctorates"}

Scientific employment via contractual arrangements in 2007 and 2008 proved to be an important policy strategy for developing research capacity in Portugal by boosting the qualifications of human resources in science and technology at Portuguese R\&D units. The measure also contributed to mobility of faculty and internationalisation of the Portuguese S\&T system. It stimulated major changes in the academic community and significantly contributed to the renewal of teaching and research staff. The policy initiative continued up to 2012, when the scope of the policy initiative and the number of contracts offered to researchers decreased considerably. The policy measure was renamed "Investigador FCT" (FCT Investigator), and a total of 80 vacancies were available in 2012 to which 1175 applications were submitted by May. ${ }^{7}$ In 2013, there were 1479 applications, and 209 were approved for funding. In both calls, there were a total of 2655 applications, and barely $13.9 \%$

6 In 2009, the number of positions decreased to about 540 accepted applicants at approximately 70 institutions (source FCT).

7 FCT Newsletter: http://newsletter.fct.pt/h/n1/investigador-fct.php 


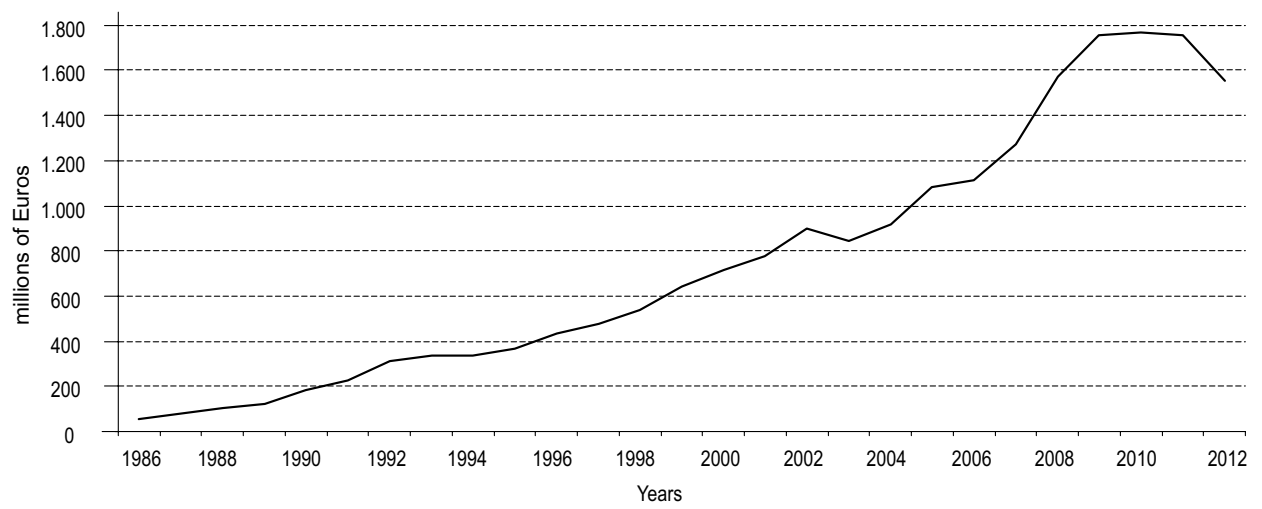

Figure 1 Funding of science and technology in millions of Euros and between the years of 1986 and 2012 Source: DGEEC / Statistics Office for Education and Science.

were approved. Out of 342 research contracts, $26 \%$ of doctoral researchers were foreigners and around $50 \%$ were women (FCT, 2014). Horta and Hasanefendic argue that, "this downsized number of vacancies of the program raises concerns with regards to future scientific and academic employment, and the ability to integrate young doctorates with some years of postdoctoral experience into Portuguese research and academic institutions" (2015: 213). Vacancy cuts were also accompanied by budget cuts for science and technology as shown in figure 1 .

These cuts could potentially threaten the existing research base and lead to yet another era of brain drain (see Fontes, 2007; Belyaev, 2010; Docquier and Rapoport, 2012). This would reverse the trend of the last decade, which was one of "brain gain" (Heitor, Horta and Mendonça, 2014).

\section{Discussion}

The emergence of the "Commitment to Science" program had a strong impact on the development of research capacity in S\&T in Portugal. Table 1 exemplifies the achievements of the program in relation to the targets of developing human research capacity at private and public R\&D units in Portugal. The Portuguese S\&T system experienced increases in the number of doctorates, researchers per 1000 of active population and budget allocation to both public and private $R \& D$ from the implementation of the program.

Table 2 shows the increase in the number of doctoral students per year, which grew from 945 in 1994 to 2030 in 2007 (2.7 new doctorates for 10,000 of active population in 2008 as opposed to 0.68 in 1990), and figure 2 shows that the number of researchers in R\&D in higher education increased from 10,956 in 2005 to 28,830 in 2010 (GPEARI/MEC, 2011a; 2011b; GPEARI/MCTES, 2011c; OECD, 2011), which made a significant impact on developing national scientific capacity (see Fontes, 
Table 1 Policy measures under the "Commitment to Science" policy program targeting human resource in S\&T improvement and the achievements before 2010

\begin{tabular}{|c|c|}
\hline Policy initiatives (targets for 2010) & Statistics \\
\hline $\begin{array}{l}\text { Reach } 5.5 \text { researchers for } 1000 \text { of active population (in } 2003 \\
\text { there were } 3.5 \text { ) }\end{array}$ & 7.2 researchers in 2008 (see figure 3 ) \\
\hline Pass from 1000 to 1500 new PhDs per year & $\begin{array}{l}2030 \text { new PhDs in 2007; } 1926 \text { in } 2009 \text { (see } \\
\text { figure 2) }\end{array}$ \\
\hline Increase $\mathrm{PhD}$ scholarships by $60 \%$ via open competition & $\begin{array}{l}\text { Increase of } 67 \% \text { between } 2007 \text { and } 2010 \text { (see } \\
\text { http://www.fct.pt/estatisticas/bolsas/) }\end{array}$ \\
\hline $\begin{array}{l}\text { Hire } 1000 \text { national and international PhDs with exceptional merit } \\
\text { to work at Portuguese higher education institutions and R\&D } \\
\text { units }\end{array}$ & $\begin{array}{l}\text { cc. } 1200 \text { new doctoral researchers by } 2009 \text {; } \\
41 \% \text { foreigners (MCTES, 2011) }\end{array}$ \\
\hline $\begin{array}{l}\text { Adapt and consolidate the immigration legislation and supporting } \\
\text { mechanisms to enable highly qualified human resources from } \\
\text { another countries to develop their work in Portugal and make it } \\
\text { easier for their families to join }\end{array}$ & $\begin{array}{l}\text { Portugal implemented a simplified visa } \\
\text { regimes for highly qualified incoming } \\
\text { researchers (see } \\
\text { http://www.fct.pt/documentos/Info_estrangeiro } \\
\text { s_alt_qualif_EN.pdf) }\end{array}$ \\
\hline
\end{tabular}

Table 2 PhD Scholarships awarded by JNICT and FCT (from 1997), by scientific domain, between 1994 and 2012

\begin{tabular}{rrrrrrrrr}
\hline Year & $\begin{array}{c}\text { Exact } \\
\text { Sciences }\end{array}$ & $\begin{array}{c}\text { Natural } \\
\text { Sciences }\end{array}$ & $\begin{array}{c}\text { Engineering } \\
\text { and } \\
\text { Technology }\end{array}$ & $\begin{array}{c}\text { Medical } \\
\text { Sciences }\end{array}$ & $\begin{array}{c}\text { Agrarian } \\
\text { Sciences }\end{array}$ & $\begin{array}{c}\text { Social } \\
\text { Sciences }\end{array}$ & Humanities & Total \\
\hline 1994 & 150 & 143 & 330 & 129 & 69 & 82 & 42 & 945 \\
1995 & 115 & 58 & 200 & 56 & 24 & 75 & 26 & 554 \\
1996 & 72 & 91 & 169 & 95 & 42 & 89 & 49 & 607 \\
1997 & 96 & 97 & 135 & 73 & 22 & 114 & 62 & 599 \\
1998 & 135 & 127 & 175 & 46 & 31 & 161 & 84 & 759 \\
1999 & 90 & 135 & 155 & 78 & 26 & 149 & 81 & 714 \\
2000 & 118 & 171 & 139 & 80 & 35 & 162 & 92 & 797 \\
2001 & 120 & 169 & 152 & 85 & 20 & 128 & 93 & 767 \\
2002 & 118 & 192 & 149 & 86 & 34 & 172 & 97 & 848 \\
2003 & 93 & 137 & 133 & 108 & 30 & 104 & 82 & 687 \\
2004 & 148 & 218 & 285 & 151 & 53 & 245 & 133 & 1233 \\
2005 & 138 & 181 & 245 & 159 & 43 & 264 & 165 & 1195 \\
2006 & 200 & 281 & 403 & 200 & 72 & 362 & 223 & 1741 \\
2007 & 184 & 289 & 438 & 246 & 78 & 479 & 316 & 2030 \\
2008 & 188 & 269 & 452 & 216 & 85 & 422 & 330 & 1962 \\
2009 & 171 & 239 & 491 & 211 & 67 & 408 & 339 & 1926 \\
2010 & 137 & 218 & 421 & 206 & 61 & 370 & 267 & 1680 \\
2011 & 111 & 211 & 377 & 229 & 70 & 360 & 273 & 1631 \\
2012 & 102 & 174 & 353 & 200 & 68 & 206 & 143 & 1246 \\
Total & 2486 & 3400 & 5202 & 2654 & 930 & 4352 & 2897 & 21921 \\
\hline
\end{tabular}

Source: FCT, data extracted on the 22nd of January 2014.

2004; Soares and Trindade, 2004; Eurydice, 2010). By 2008, there were more than 45,000 researchers engaged in research activities at public and private R\&D institutions in Portugal, compared to fewer than 20,000 in 2000 (GPEARI/MEC, 2011a). The numbers indicate that Portugal surpassed the average OECD level in terms of 


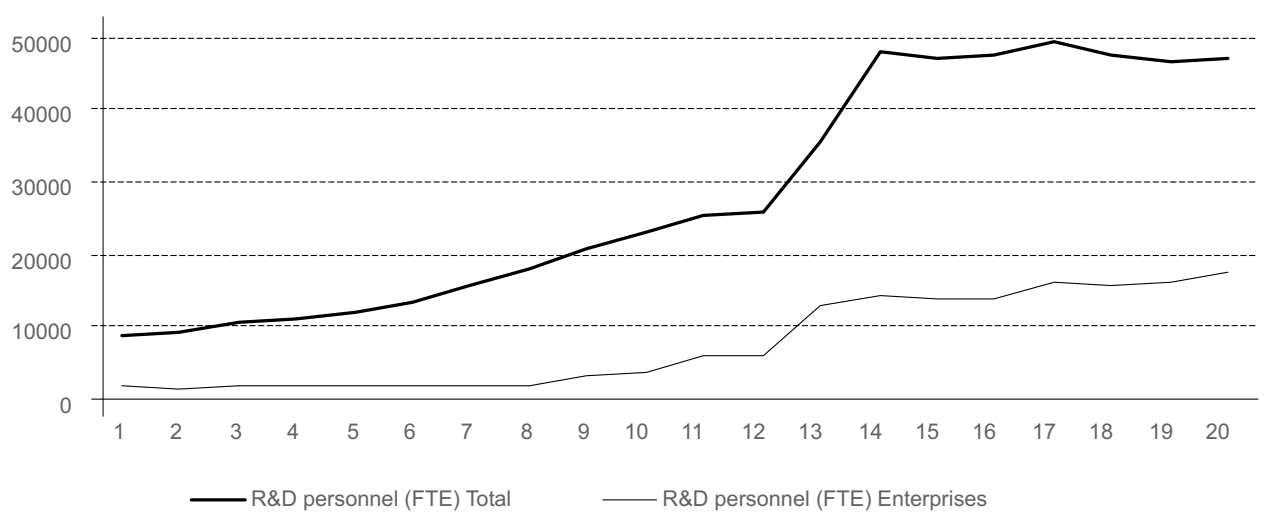

Figure 2 Total researchers (as measured in "full time equivalent", FTE) in Portugal and in business (enterprise) sector

Source: DGEEC / Statistics Office for Education and Science.

the number of researchers per thousand workforce, attaining 8.2 full time researchers per thousand workforce in 2009 (MCTES, 2011; Pordata, 2012).

A significant increase in the total number of researchers in the country (figure 2 ) was matched with an increase in the total number of R\&D personnel in the business sector (enterprises), which nearly tripled from 4014 to 10,363 researchers between 2005 and 2010, and represents around $24 \%$ of the total researchers working in Portugal (GPEARI/MEC, 2011a).

The rapid expansion in the number of researchers increased the size of $R \& D$ units, specifically associate laboratories where the number of $\mathrm{PhDs}$ per unit was about 58 (Sunkel, 2009). Such an expansion of the scientific system contributed to the competitiveness of Portugal in the European context, showing that Portugal does not necessarily lag behind other more developed European countries in scientific capabilities and output (MCTES, 2011).

Portuguese science has shown remarkable growth levels in the past years and decades: R\&D activity has almost tripled and the number of researchers has increased more than six times. The program "Commitment to Science" and the policy measure of contracting a minimum of 1000 doctorates seems to have had a considerable influence in reaching these aims and proved to be successful not only in fostering scientific employment and developing human resources at $R \& D$ units in Portugal, but also in scientific expansion and internationalisation of R\&D units. However, in spite of the growth in the number of researchers in Portugal and related gross expenditure, ${ }^{8}$ research funding available per researcher or research expenditure per inhabitant are both still relatively low compared with the

8 Portugal is still far from the R\&D investment level of other small or medium-sized European countries such as Belgium (1.96\%), Finland (3.96\%), Slovenia (1.86\%) and Denmark (3.02\%) for instance, and below the EU27 average (1.90\%) (OECD, 2012). 
majority of European countries (OECD, 2011; 2012). Public investment in R\&D positively influences the growth of the country's GDP (Coccia, 2008), as well as private spending on R\&D (Azoulay et al., 2015; Lööf and Heshmati, 2005); such investment benefits research development at small and medium enterprises (Gonzalez and Pazó, 2008), compensates for market failures (Bozeman and Sarewitz, 2005) and increases scientific production (Wang and Shapira, 2015). Following this rationale, if Portugal wants to secure economic growth and position itself as one of European's most innovative countries, it needs to ensure financial sustainability for its well-developed research base and take advantage of the R\&D potential in the country to excel in science and technology.

\section{Conclusion and policy implications}

This research paper aimed to analyse and describe the formation and implementation of the policy initiative related to development of (human) research capacity at public and private R\&D institutions within the "Commitment to Science" policy program, as well as address its outputs and aftermath. The analysis focused on the policy measure of contractual arrangements for 1000 doctorates fostered under the program and used policy cycle as a methodological framework for analysis. The policy measure and the overall program contributed to the development of human research capacity at public and private $R \& D$ institutions and internationalised the higher education research base in Portugal. The policy was well prepared and designed to combat specific problems of transparency that could potentially be raised at the EU level. Moreover, the policy design was followed by stable and coherent funding up to 2010/2011, which furthered policy success. This success is obvious when looking at the increased levels of doctorates and post-doctorates, and researchers at research units, percentage of foreign scientists at Portuguese research units and public and private R\&D expenditure since 2006. However, despite these positive results, Portuguese S\&T has been experiencing serious setbacks with recent policy developments in terms of scientific employment and development of research capacity at R\&D units (Melo, 2012). Since 2011, and with the establishment of a new Government that focused on macroeconomic stabilisation after the financial and economic crisis hit Portugal, there were significant cuts in terms of investment in research and development and a lack of priority in addressing science and technology policies at the highest political level. By 2013, most of the contracts of the selected candidates, the 1000 researchers contracted through the "Commitment to Science" program in 2007 and 2008, had expired, and only 400 new vacancies were opened by the FCT, leaving the existing researchers to either abandon research or the country (see Heitor, 2015). Public research institutions were not able to take in all the researchers due to insufficient funding, and the private sector experienced difficulties in absorbing the highly qualified personnel (Godinho and Simões, 2013). The low participation of the private sector in employment of researchers is a result of both the economy, which lacks a technologically sophisticated industrial sector (Godinho, 2013; Barreiros, 2006), and policy choices that 
have stimulated business competitiveness without initiatives to encourage innovation in companies (Heitor, 2015). In general, this is illogical, as in order to stimulate business competitiveness companies need to innovate (e.g. Reche and Tadeo, 2011). Innovation is a result of research performance and usually in modern laboratories and research centres staffed by the most talented researchers (MIT, 2015). Declining public investment in R\&D therefore does not only lead to emigration of the highly skilled and the reduction of research capacity, but also heavily hampers innovation and with it business competitiveness that recent policies seek. Only recently, the Government has agreed to subsidise the private employment of 1220 researchers currently employed at public research institutions in the desire to increase the number of doctorates employed by companies and at the same time contribute to business competitiveness. ${ }^{9}$ In the first year of employment, the Government will fund $75 \%$ of the salaries, in the second $50 \%$ and the third $25 \%$. However, this is a shortsighted solution without a comprehensive policy to foster further scientific development and technological innovation in the country.

Portugal needs to change the course of its S\&T policy, and its relation to human resources in S\&T, and revisit public funding mechanisms for R\&D if it wants to enhance innovation, expand research capacity and stimulate economic growth. Keeping in mind economic austerity and the country's technologically underdeveloped industrial base with scarce opportunities for increasing $R \& D$ expenditure among business enterprises, Portugal should devise new models of public funding and governance, and establish new S\&T policies to support the realities of the current socioeconomic context, one that maintains a global outlook for advancement of knowledge. These policies should also connect with industrial policies and go hand in hand with the development of the country's business and industrial base. The analysis of this paper testifies that although we witnessed an increase in the number of researchers in the country since the implementation of the policy program "Commitment to Science," there were problems in their long-term absorption by the underdeveloped industrial system and public institutions, both of which suffered from lack of funding. Policies in S\&T should be created in collaboration with other parts of the country's economic system and with an aim to generate innovation.

\section{Limitations}

This research paper was a systematic review of a policy initiative to develop (human) research capacity within the "Commitment to Science" policy program, and the analysis was based solely on documented data and a review of existing literature. Further research should extend the analysis of this paper in an empirical way so that the evidence on the impacts of the policy program and the contribution to

9 See: http://www.publico.pt/economia/noticia/governo-quer-transferir-1220-investigadores-doestado-para-as-empresas-1681961 
the policy initiative are clearer and not merely suggestive. In addition, the paper did not take into account most recent developments in the science and technology policy which are underway since 2015/2016.

To a large extent the paper is descriptive and the methodological constraints apply. The policy cycle was used as a framework to organise a detailed description of the initiative and the program and was not intended to analyse different stages in depth. Additional in-depth qualitative or quantitative examinations of the impact of the program on the Portuguese R\&D landscape and in international comparison are necessary and would provide a substantive contribution to academic studies concerned with policy implementation and understanding the process behind adaptation to policy in comparative terms.

\section{References}

Araújo, E. R. (2009), “With a rope around their neck: grant researchers living in suspended time", New Technology, Work and Employment, 24 (3), pp. 230-242.

Azoulay, P., J. S. Graff, D. Li, and B. N. Sampat (2015), "Public R\&D investments and private-sector patenting: evidence from NIH funding rules", NBER Working Paper, n. $\stackrel{\circ}{20889}$.

Barreiros, A. (2006), O Desenvolvimento dos Serviços Informação Intensivos em Portugal, master thesis submitted for the Master Degree of Economics and Management of S\&T and Innovation at ISEG/UTL.

Belyaev, D. (2010), “The EU's 'Lisbon Strategy' one decade on: where is Portugal on the way to a knowledge society?", Journal of Contemporary European Research, 6 (3), pp. 353-375.

Bozeman, B., and D. Sarewitz (2005), “Public value failures and science policy”, Science and Public Policy, 32 (2), pp. 119-136.

Bridgman P., and G. Davis (2003), "What use is a policy cycle? Plenty, if the aim is clear", Australian Journal of Public Administration, 62 (3), pp. 98-102.

Coccia, M. (2008), "Science, funding and economic growth: analysis and science policy implications", World Review of Science, Technology and Sustainable Development, 5 (1), pp. 1-27.

Docquier, F., and H. Rapoport (2012), "Globalization, brain drain and development", Journal of Economic Literature, 50 (3), pp. 681-730.

Eurydice (2010), National System Overviews on Education Systems in Europe and On-Going Reforms, Brussels, European Commission.

FCT (2009), Mais Cientistas para Portugal, Lisbon, FCT.

FCT (2012), Regulations for Advanced Training and Qualification of Human Resources 2012, available at: http://www.fct.pt/apoios/bolsas/regulamento.phtml.en (last accessed August 2016).

FCT (2014), "Estatísticas da Fundação para a Ciência e a Tecnologia: Emprego Científico", available at: https://www.fct.pt/estatisticas/emprego-cientifico/docs/ Doc_Emprego_Cientifico_PT.pdf (last accessed August 2016).

File, J. (2008), Higher Education in Portugal, IHEM country report, Twente, CHEPS. 
Fischer, F., and G. J. Miller (Eds.) (2006), Handbook of Public Policy Analysis. Theory, Politics, and Methods, Boca Raton, FL, CRC Press.

Fontes, M. (2004), “Emprego científico ou emprego para cientistas? Situação e perspectivas do mercado de trabalho para doutorados em Portugal", paper presented at the conference "Emprego Científico em Portugal. Que Futuro?", Lisbon.

Fontes, M. (2007), "Scientific mobility policies: how Portuguese scientists envisage the return home", Science and Public Policy, 34 (4), pp. 284-298.

Gago, M. (1990), Manifesto para a Ciência em Portugal, Viseu, Gradiva.

Godinho, M. M. (2013), Inovação em Portugal, Lisbon, Fundação Francisco Manuel dos Santos.

Godinho, M. M., and V. C. Simões (2013), Erawatch Country Reports Portugal 2012, Brussels, European Commission.

Gonçalves, F., and J. M. G. Caraça (1987), “Science and technology in Portugal: a perspective", Science and Public Policy, 14 (3), pp. 155-158.

González, X., and C. Pazó (2008), “Do public subsidies stimulate private R\&D spending?", Research Policy, 37 (3), pp. 371-389.

GPEARI/MCTES (2011a), Fluxos e Situação Profissional dos Doutorados em Portugal, Lisbon, MCTES.

GPEARI/MCTES (2011b), Docentes do Ensino Superior. 2001-2009, Lisbon, MCTES.

GPEARI/MCTES (2011c), Diplomados no Ensino Superior (2000/01-2009/10), Lisbon, MCTES.

GPEARI/MEC (2011a), IPCTN10. Resultados Provisórios (Novembro 2011), Lisbon, MEC.

GPEARI/MEC (2011b), Inscritos no Ensino Superior (2000/01-2010/11), Lisbon, MEC.

Heitor, M. (2015), Portugal 2015. Who is Against the Future of Science and the Advancement of Knowledge?, available at:

http://www.manifesto2015.com/docs/MHeitorPortugal-2015-new-horizons-MHeito r-v18may2015.pdf (last accessed August 2016).

Heitor, M., and H. Horta (2012), “Science and technology in Portugal: from late awakening to the challenge of knowledge integrated communities", in G. Neave and A. Amaral (Eds.), Higher Education in Portugal, 1974-2009. A Nation, a Generation, Dordrecht, Springer, pp. 179-226.

Heitor, M., H. Horta, and J. Mendonça (2014), “Developing human capital and research capacity: science policies promoting brain gain", Technology Forecasting and Social Change, 82, pp. 6-22.

Horta, H., and S. Hasanefendic (2015), "Young doctorates in a fast-changing higher education system: the case of Portugal", in M. Yudkevich, P. G. A. Altbach and L. E. Rumbley (Eds.), The Future of the Academic Profession. Young Faculty in International Perspective, Albany, NY, Suny Press, pp. 201-227.

Howlett, M., and M. Ramesh (2003), Studying Public Policy. Policy Cycles and Policy Subsystems, Oxford, Oxford University Press.

Jann, W., and K. Wegrich (2006), "Theories of the policy cycle”, in F. Fischer, G. Miller and M. Sidney (Eds.), Handbook of Public Policy Analysis. Theory, Politics, and Methods, Boca Raton, FL, CRC Press, pp. 43-62. 
Laranja, M. (2012), “Network governance of innovation policies: the Technological Plan in Portugal", Science and Public Policy, 39, pp. 655-668.

Lööf, H., and A. Heshmati (2005), “The impact of public funds on private R\&D investment: new evidence from a firm level innovation study", MTT Discussion Papers, n. ${ }^{\circ}$ 3, pp. 1-26.

Mayntz, R. (1983), “The conditions of effective public policy: a new challenge for policy analysis", Policy $\mathcal{E}$ Politics, 11 (2), pp. 123-143.

MCTES (2010), “A new landscape for Science, Technology and Tertiary Education in Portugal", available at: http://www.dges.mctes.pt/NR/rdonlyres/90DBE647-5CB6-4846-B88F-101180D9E42 5/4832/New_landscapes_v18Jun20102.pdf (last accessed August 2016).

MCTES (2011), "Science, technology and tertiary education in Portugal 2011", paper presented at the OECD's Seminar on Science, Technology, Innovation and Higher Education Policy Developments in Portugal, Paris.

Melo, D. (2012), Ciência para o Futuro. A Propósito do Relatório Estratégico do Conselho Científico das Ciências Sociais e das Humanidades, available at: http://www.scielo.oces.mctes.pt/scielo.php?script=sci_arttext\&pid=S0003-25732012 000100010 (last accessed February 2015).

MIT (2015), The Future Postponed. Why Declining Investment in Basic Research Threatens a U.S. Innovation Deficit, Washington, DC, MIT Washington Office.

Mitchell, R., B. Agle, and D. Wood (1997), “Toward a theory of stakeholder identification and salience: defining the principle of who and what really counts", The Academy of Management Review, 22 (4), pp. 853-886.

OECD (2011), Science, Technology and Industry Scoreboard 2011. Innovation and Growth in Knowledge Economies, Paris, OECD.

OECD (2012), Main Science and Technology Indicators (MSTI). 2011/2 Edition, Paris, OECD.

OECD (2012a), Education at a Glance Portugal 2012, Paris, OECD.

Pordata (2012), Total Personnel and Researchers Involved in RED Activities. Full-Time Equivalent per 1,000 Active Persons, available at: http://www.pordata.pt/en/Portugal/Total+personnel+and+researchers+involved+in +research+and+development+activities+\%28R+D\%29+full+time+equivalent+per+1+ 000+active+persons-1097 (last accessed August 2016).

Reche, A. G., and P. J. Tadeo (2011), “Innovation and business competitiveness: is our production model resilient?", Mètode Science Study Annual Review, 1, pp. 212-217.

Rollo, M. F. F. G., M. T. P. B. Ribeiro, and P. C. V. Meireles (2013), “O arquivo nacional de ciência e tecnologia: política e organizacão da ciência em Portugal", revista Acervo, 26 (2), pp. 207-219.

Soares, V. M., and A. R. Trindade (2004), "The attractiveness of the academic career: country report Portugal", in J. Enders and E. de Weert (Eds.), The International Attractiveness of the Academic Workplace in Europe, Frankfurt/Main, GEW, pp. 349-372.

Sunkel, C. (2009), Research Units Evaluation-2007. Global Report, Lisbon, FCT.

Wang, J., and P. Shapira (2015), “Is there a relationship between research sponsorship and publication impact? An analysis of funding acknowledgments in nanotechnology papers", PloS ONE, 10 (2), DOI: 10.1371/journal.pone.0117727 
Sandra Hasanefendic. PhD student at ISCTE-IUL Portugal and Vrije Universiteit Amsterdam. Researcher at CIES-IUL, Lisbon, Portugal and Center for Innovation, Technology and Policy Research, IST, Lisbon, Portugal.

Receção: 7 de março de 2015 Aprovação: 20 de maio de 2016 
